\title{
ВІРТУАЛЬНА, ДОПОВНЕНА І ЗМІШАНА РЕАЛЬНІСТЬ: СУТНІСТЬ ПОНЯТЬ ТА СПЕЦИФІКА ВІДПОВІДНИХ КОМП’ЮТЕРНИХ СИСТЕМ
}

\section{- Волинець Вікторія Олексіївна}

Кандидат культурології,

ORCID: 0000-0003-3783-508X, e-mail: vika-volynets@ukr.net, Київський національний університет культури і мистецтв, вул. Є. Коновальця, 36, Київ, Україна, 01133

\section{- Для цитування:}

Волинець, В.О. (2021). Віртуальна, доповнена і змішана реальність: сутність понять та специфіка відповідних комп'ютерних систем. Питання культурології, (37), 231-243. doi: https://doi. org/10.31866/2410-1311.37.2021.237322.

\section{- Анотація}

Мета статті - розкрити сутність понять «віртуальна реальність», «доповнена реальність», «змішана реальність»; з'ясувати типологічні відмінності відповідних комп'ютерних систем. Методологія дослідження ґрунтується на застосуванні діалектичного методу, що дав змогу розкрити специфіку віртуальної / доповненої / змішаної реальностей крізь призму діалектики взаємодії техніки та людини. Наукова новизна полягає в розмежуванні понять «віртуальна реальність», «доповнена реальність», «змішана реальність» - ключових категорій імерсивних інформаційних технологій, неправомірність вживання яких як синонімів призводить до необґрунтованого використання специфічної лексики. Крім того, у статті розкрито сутність та головні відмінності між комп'ютерними VR-, AR-, XR-системами, що $€$ вкрай важливим у межах української культурології - науки, яка наразі активно займається дослідженням безпрецедентних суспільних змін під впливом новітніх інформаційно-комунікаційних технологій. Висновки. Наявна в науці різноплановість думок вчених і практиків щодо питань типології віртуальної реальності, як і понять «віртуальна реальність», «доповнена реальність», «змішана реальність», пояснюється неправомірним ототожненням технологій віртуальної реальності кінця 1990-х рр. і сучасних розробок у цій сфері; відсутністю чітких критеріїв типології і відповідних методологічних підходів, що ускладнює процес класифікації видів віртуальної реальності; швидкими темпами розвитку VR-технологій, що провокує істотне відставання теорії від практики. Тим часом сфера досліджень віртуальної реальності продовжує невпинно розширюватися, триває інтеграція VR з різними сфрерами людського життя. VR- i AR-технології набувають популярності у культурних, освітніх, ігрових, бізнес-середовищах тощо. Порушена проблематика лише починає вивчатися в українській культурології, що спонукає до глибшого проникнення 
у сутність процесів, які відбуваються в культурі під впливом новітніх інформаційнокомунікаційних розробок.

Ключові слова: віртуальна реальність; доповнена реальність; змішана реальність; комп'ютерна віртуальна реальність; комп'ютерні технології

\section{- Вступ}

Увага наукової спільноти до поняття і явища віртуальної реальності (VR) стрімко зросла за останні 2-3 роки й цей процес триває, оскільки з'являється все більше різноманітного обладнання і технологій, а головне - розширюється поле практичного застосування технології віртуальної реальності в різних сфрерах. З'явилися такі терміни, як «віртуальна реальність», «доповнена реальність», «змішана реальність», а також «контент з ефектом занурення». Однак, як свідчить практика, у багатьох науковців відсутнє чітке уявлення про те, що означають ці вислови і чим вони відрізняються один від одного. Наразі немає усталеної термінології, що б застосовувалася для визначення типів віртуальної реальності. Спроба зрозуміти, що криється за кожним із цих термінів може призвести до замішання, адже в їх тлумаченні чимало розбіжностей. Проте, мабуть, саме ці терміни, що позначають глибину взаємодії людини з віртуальною реальністю, і будуть найбільш популярними й вживаними протягом найближчих кількох років і десятиліть. Застосування вказаних технологій у сфері культури передбачає чітке розуміння їх сутності, технічного й апаратного забезпечення, особливостей їх використання. Розкриття сутності та головних відмінностей між комп'ютерними VR-, AR-, XR-системами $€$ вкрай важливим у межах української культурології - науки, яка наразі активно займається дослідженням безпрецедентних суспільних змін під впливом новітніх інформаційно-комунікаційних технологій.

Комп'ютерна віртуальна реальність $€$ новим предметом наукових досліджень, проте у межах гуманітарних дисциплін вже зроблені серйозні спроби їі осмислення. Чимало праць, в яких об'єктом вивчення $є$ комп'ютерна VR належать представникам таких наук, як психологія і філософрія. Це роботи М. Журби (2014), А. Засєкіна (2012), А. Лучинкіної (2014), М. Опьонкова (Опенков, 2001), Е. Смерічевського (2002) та ін. Трактування віртуальної реальності з позицій комп'ютерних наук представлене здобутками М. Крюгер (Krueger, 1991), Дж. Ланьє (Lanier, 2010) та ін. Значущими дослідженнями у сфері соціально-культурних практик, що трансформуються під впливом комп'ютерної віртуальної реальності є напрацювання 3. Баумана (2008), Е. Гідденса (Гидденс, 2005) та ін. Та попри наявність доволі широкого масиву наукових розвідок, швидкі темпи розвитку VR-технологій й досі провокують суттєве відставання теорії від практики. Зокрема, вимагає уточнення і подальшого ґрунтовного дослідження типологія віртуальної реальності, оскільки від вирішення цього завдання залежить обґрунтованість і доцільність вживання дотичних термінів, словосполучень і концепцій, а також усвідомлення можливостей їх застосування у сорері культури. 


\section{- Мета статті}

Мета статті - розкрити сутність понять «віртуальна реальність», «доповнена реальність», «змішана реальність»; з'ясувати типологічні відмінності відповідних комп'ютерних систем. Методологія дослідження ґрунтується на застосуванні діалектичного методу, що дав змогу розкрити специфіку віртуальної / доповненої / змішаної реальностей крізь призму діалектики взаємодії техніки та людини. Наукова новизна полягає в розмежуванні понять «віртуальна реальність», «доповнена реальність», «змішана реальність» - ключових категорій імерсивних інформаційних технологій, неправомірність вживання яких як синонімів призводить до необґрунтованого використання специфічної лексики.

\section{- Виклад матеріалу дослідження}

Сьогодні теоретики й практики все частіше констатують фракт стирання меж між віртуальним і реальним світом, що відкриває настільки неймовірні можливості, про які не так давно лише франтазували письменники. Однак в останні роки комп'ютерна віртуальна реальність подолала шлях від чергового нового віяння до технології, час якої настав: тепер можна створювати реалістичні зображення, звуки та інші відчуття, що здатні перенести людину захоплюючий вигаданий світ. Своєю чергою доповнена реальність також привносить елемент віртуальності в оточуючу дійсність і підсилює впевненість у тому, що обидві ці технології надзвичайно вплинуть на майбутнє. Змішана реальність поєднує реальний світ і цифрові елементи, завдяки чому людина може взаємодіяти з фізичними й віртуальними предметами та оточенням одночасно і маніпулювати ними за допомогою новітніх технологій сприйняття і візуалізації. Різницю між цими трьома поняттями інколи вкрай складно зрозуміти, особливо непідготовленому користувачу, попри швидкість виникнення і розповсюдження технологій та їх відносну доступність. На додаток, їх поява частково пов'язана з тим, що бізнес-компанії пропонують власні назви для технологій віртуальної реальності. Наприклад, термін «змішана реальність», запропонований ще в 1994 році, згодом відійшов на другий план, поступившись місцем доповненій і віртуальній реальностям. Але в останні роки компанія «Microsoft» почала активно використовувати «змішану реальність» для просування на ринку свого продукту HoloLens. Отож, експертами й постачальниками обладнання заведено розрізняти ці терміни в такий спосіб:

- доповнена реальність - проєктування будь-якої цифрової інфрормації (зображення, відео, текст, графріка та ін.) поза екраном будь-яких пристроїв, внаслідок чого реальний світ доповнюється штучними елементами і новою інформацією. Доповнена реальність може бути реалізована за допомогою додатків для звичайних смартфонів і планшетів, окулярів доповненої реальності, стаціонарних екранів, проєкційних пристроїв та інших технологій;

- змішана реальність - проєктування тривимірних віртуальних об'єктів або голограм на фрізичний простір, що дає змогу переміщатися навколо віртуального об'єкта, оглядати його з усіх боків і у разі потреби всередині. Змішана реальність зазвичай вимагає спеціального обладнання: окулярів або шоломів. У змішаній реальності віртуальні образи привносяться в фізичний простір, візу- 
алізуються і розташовуються відповідно до предметів реальності так, щоб вони сприймалися як справжні. Людина продовжує взаємодіяти з фізичним світом, в якому одночасно присутні й віртуальні об'єкти, які іноді майже неможливо відрізнити від реальних;

- віртуальна реальність - занурення людини в заздалегідь змодельований світ і часткове (в перспективі - повне) ізолювання її від світу фрізичного, для чого використовуються шоломи віртуальної реальності та інші спеціальні пристрої. Розробники прагнуть імітувати взаємодію зі створюваною ними псевдореальністю шляхом впливу на всі органи чуття людини. Під цим поняттям розуміється комп'ютерна віртуальна реальність, у такий спосіб уточнюючи за допомогою якого засобу людина занурюється в цю реальність, тим самим відокремлюючи це поняття від філософського осмислення віртуального і віртуальної реальності.

Тенденції розвитку VR у світі та специфічні ознаки, за якими виокремлюються різні типи реальностей, - рівень або глибина занурення у віртуальний простір, реальність відображуваних віртуальних об'єктів і своєрідний спосіб взаємодії з ними - дають теоретикам і практикам підстави для розробки ії типології. Відповідно до розглянутих ключових термінів комп'ютерної віртуальної реальності, тобто залежно від міри занурення у відповідну реальність, розрізняють й відповідні ії три типи.

Доповнена реальність (augmented reality, AR) - термін, запропонований Томасом Коделлом (Thomas Caudell) в 1992 році, що набув поширення завдяки розповсюдженню VR-технологій. Іноді його вживають як синонім до понять «розширена реальність», «поліпшена реальність», «збагачена реальність», «збільшена реальність» (Как работает дополненная реальность, 2015), однак це нелогічно, оскільки вони можуть бути застосовані лише для позначення певних фрорм та аспектів практичного застосування доповненої реальності. У цьому контексті варто звернутися до праці Рональда Азуми «Дослідження доповненої реальності», в якій автором сформульовані основні принципи, характерні для систем з доповненою реальністю: комбінування реального та віртуального; взаємодія в режимі реального часу; робота з тривимірним простором (Azuma, 1997). Тобто у вузькому розумінні доповнену реальність можна визначити як технологію інтеграції віртуальних об'єктів в реальний світ. С. Макеєв трактує доповнену реальність як феномен просторово-часового континууму, який поєднує в собі об'єктивну і віртуальну реальність і має ряд специфічних якостей і властивостей, недоступних в окремо взятих об'єктивній і віртуальній реальностях (С. Н. Макеев \& А. Н. Макеев, 2013). Загалом можна констатувати, що поняття доповненої реальності охоплює кілька аспектів: візуалізація, контекстні операції (тригери), візуальні вказівки (асистування) (Кравцов, 2016). Інакше кажучи, якщо поточні технології користувацьких інтерфейсів сфокусовані переважно на взаємодії людини і комп'ютера, то доповнена реальність за допомогою комп'ютерних технологій пропонує вдосконалення інтерфейсу людини і реального навколишнього світу. Концепція доповненої реальності пропонує досконаліший користувацький інтерфейс для візуалізації внаслідок сукупності способів управління і візуалізації. 
Доповненій реальності притаманні унікальні способи відображення візуальної інформації, зокрема візуалізації тривимірних об'єктів. Засобами AR об'єкт може бути візуалізований безпосередньо в контексті його експлуатації. Прикладом може слугувати предмет меблів, візуалізований в інтер'єрі, рослини на присадибній ділянці, архітектурний об'єкт на місцевості, комунікації в стіні будівлі, результати ультразвукового сканування, спроєктовані на пацієнта під час операції. Управління ракурсом об'єкта здійснюється природними рухами голови користувача або пристрою і $є$ зрозумілим й ефеективним.

Візуалізація засобами AR може бути використана при прийнятті рішень під час розробки, дизайну, при здійсненні покупки. Також можливе успішне застосування в освітніх цілях та інших сферах. Засобами AR може бути ефрективно зазначено місце розташування необхідного об'єкта і контекстно в тривимірному просторі проілюстровані операції, які необхідно здійснити. Такі візуальні вказівки можуть бути призначені і для фахівців, і для непідготовлених користувачів, водночас процес може бути розділений на певні етапи. Окремим випадком візуальних вказівок $€$ навігація на місцевості або всередині приміщень. Технологія доповненої реальності дає змогу природним чином візуально відобразити маршрут до вибраного користувачем місця розташування (наприклад, відображаючи вказівки безпосередньо на дорозі). Користувачеві не потрібно відволікатися на паперові карти чи екран навігатора, що особливо важливо при керуванні транспортним засобом.

Однією з основних умов масового впровадження AR-технологій у повсякденне життя людини є розвиток споживчої техніки. До пристроїв, які реалізують AR належать планшети, смартфони, окуляри i, в перспективі, лінзи доповненої реальності. На планшети і смартфони необхідно встановити спеціалізоване програмне забезпечення, браузери якого можуть показувати найближчі до місця розташування користувача пам'ятки, магазини, кафе, пункти прокату, пункти обслуговування тощо, а також виконувати інші корисні функції. На мобільному телефоні доповнена реальність вперше була продемонстрована Матіасом Мерінгою (Mathias Möhring) і його колегами ще у 2004 році (Möhring et al., 2004). До стаціонарних пристроїв, які реалізують AR належать телевізор, екран комп'ютера. Так, на екран телевізора виводиться вже доповнене зображення (наприклад, під час трансляції футбольних і хокейних матчів), для комп'ютера - карти Google в режимі «Satellite», коли на супутниковий знімок накладаються назви вулиць і визначних пам'яток. До спеціальних засобів належать спеціалізовані шоломи військових пілотів: на скло шолома виводиться необхідна пілоту важлива інфрормація, і він може сприймати ії, не відводячи погляд від приладової панелі, економлячи у такий спосіб інколи дорогоцінні секунди (IT-Enterprise, б.г.).

З 2017 року компанії-лідери все активніше застосовують інноваційні AR-технології для реклами в роздрібній торгівлі, особливо в дитячій продукції. Невпинно продовжує зростати і ринок AR- i VR-ігор. Головним трендом 2020 року маркетологи називають використання WebAR (or web-based augmented reality), тобто AR без попереднього завантаження додатків. WebAR - це цифрова технологія, яка активується тригерами (QR-кодами або посиланнями) і дає змогу демонструвати контент доповненої реальності в браузері. Крім того, вона орієн- 
тована на доступність для якомога більшої кількості користувачів. Головна перевага такого технічного рішення полягає в тому, що користувачеві не потрібно встановлювати мобільний додаток, аби скористатися доповненою реальністю. AR-модуль інтегрується у вебсайт бренду, внаслідок чого дає можливість отримувати доступ до контенту з будь-якого мобільного пристрою з веббраузера (Live Animations, б.г.). Уже зараз багато брендів активно застосовують такі технології, і ця тенденція буде тільки зростати. Обсяг ринку WebAR сьогодні оцінюється в 16,6 млрд доларів США, а до 2025 року прогнозується його зростання до 198 млрд (Live Animations, б.г.).

Змішана (mixed reality, MR) реальність — поєднання віртуальної і доповненої реальностей, тобто накладання неіснуючих віртуальних об'єктів на навколишній світ. Типовий приклад змішаної реальності — функція Google-перекладача, яка в реальному часі за допомогою смартфона перекладає текст з однієї мови на іншу, добираючи схожий шрифт і замінюючи його. Термін «змішана реальність» був запропонований Полом Мілграмом і Фуміо Кішіно в 1994 році. У праці «Таксономія візуальних дисплеїв змішаної реальності» ними описано «Континуум Реальність-Віртуальність» - простір між реальністю і віртуальністю, між якими розташована змішана реальність, що складається з доповненої реальності ближче до реальності, і доповненої віртуальності - ближче до віртуальності (Milgram \& Kishino, 1994). Всі технології, які П. Мілграм і Ф. Кішіно позначають як змішану реальність, К. Бавор пропонує об'єднати одним терміном - імерсивні інформаційні технології (Јоусе, 2020). Але з часом термін MR поступився своїм місцем більш специфічній «доповненій реальності», яка характеризує цифрову інформацію, накладену на реальний, фрізичний світ, і «віртуальній реальності», яка застосовується для опису повністю цифрових середовищ.

Bipmуальна реальність (virtual reality, VR) - це створене технічними засобами тривимірне середовище, з яким може взаємодіяти людина та яке передається їй через зорові, слухові, тактильні чи інші відчуття. Завданням засобів VR-занурення є симуляція роботи мозку людини на сприйняття видимого як реального за допомогою спеціальних технологій (IT-Enterprise, б.г.). VR-системами називають пристрої, які більш повно, порівнюючи зі звичайними комп'ютерними системами, імітують взаємодію із віртуальним середовищем шляхом впливу на усі органи чуття людини. Таких систем у повному розумінні цього терміна поки що не існує, але при створенні віртуальної реальності розробники намагаються домогтися, щоб вона була: правдоподібною - підтримувала у користувача відчуття реальності того, що відбувається; інтерактивною - забезпечувала взаємодію із середовищем; доступною для вивчення - надавала можливість досліджувати великий, деталізований світ; створювала ефект присутності - залучала в процес і мозок, і тіло користувача, максимально впливаючи на органи чуття. Очевидно, досягнення цих цілей можливе лише за умови використання високопродуктивного апаратно-програмного забезпечення.

Віртуальну реальність зазвичай асоціюють саме з відеоіграми та розвагами, але насправді VR-можливості дуже широкі: у навчанні (дає змогу учням краще та цікавіше вивчати щось нове, особливо через високу інтерактивність, якою володіє VR-технологія; моделювання середовища тренувань у тих заняттях, 
в яких необхідна попередня підготовка: наприклад, керування літаком чи стрибки з парашутом); в науці (сприяє прискоренню досліджень молекулярного та атомного світу: занурюючись у віртуальне середовище, вчений може взаємодіяти з частинками, переставляючи їх як кубики); у медицині (навчання хірургів та безпосередньо маніпуляції на операціях, а також лікування за допомогою спеціальних VR-програм таких хвороб, як аутизм, посттравматичні стресові розлади, фоббії тощо); у дизайні та архітектурі (створення віртуальних моделей об'єктів, дослідження їх зсередини); у віртуальному туризмі та багатьох інших галузях людської діяльності.

Більш поширений термін «віртуальна реальність» означає створення повністю штучного середовища, заміщаючи людині всю аудіовізуальну інформацію, що надходить з навколишнього світу. У разі із доповненою реальністю інформація з оточуючої дійсності лише частково доповнюється віртуальним вмістом (Кравцов, 2016). С. Дацюк (б.г.) виокремлює два види віртуальної реальності: модельована віртуальна реальність та інтерактивна віртуальна реальність. Водночас С. Орєхов (Орехов, 2002) зазначає, що при незначній розбіжності ці два види роблять акцент на тому, що віртуальній реальності властива інтерактивна, змінювана діяльність для створюваних технічними системами об'єктів та для образів цих об'єктів у психіці людини. Інакше кажучи, світ віртуального не можна звести до сукупності мікросхем, - це поняття має також і психологічний характер (Орехов, 2002). В. Холодкова зазначає, що віртуальна реальність це технологія, побудована на зворотному зв'язку між людиною і світом, синтезованим комп'ютером, а також спосіб, за допомогою якого людина візуалізує цифровий світ, маніпулює ним і взаємодіє з комп'ютером. Виходячи з міри взаємодії користувача з VR-світом, Ф. Воройський, з посиланням на С. Гібіліско, розділяє віртуальну реальність на такі типи: пасивну, обстежувану інтерактивну і, власне, віртуальну (Воройский, 2003). Отже, основною метою віртуальної реальності $€$ створення цифрового світу, максимально схожого на реальний (хоча б за фрізичними ознаками), але цей світ все ж $є$ змодельованим комп'ютером (або іншим пристроєм), тобто, створеним людиною в цифровому середовищі. Доповнена реальність лише накладає елементи штучної реальності на навколишній світ. Віртуальна реальність взаємодіє лише з людиною, доповнена ще й із зовнішнім світом.

Незалежно від використовуваних технологій, системи віртуальної реальності безпосередньо пов'язані з ефектом занурення, який багато обговорюють, але не завжди розуміють його сутність. Цей термін запозичений із кіноіндустрії, де він використовується для позначення повного уявного занурення в інший, штучно створений світ. Занурення протиставляється метафоричному «вікну» - ситуації, коли глядач спостерігає за тим, що відбувається ніби ззовні. В контексті віртуальної реальності занурення - це стан, в якому користувачі забувають про те, що знаходяться у вигаданому світі. Вони сприймають цей світ усіма органами чуття, а також, на відміну від кінематографічного занурення, можуть взаємодіяти із ним. Отже, за допомогою спеціального устаткування людина може бачити, чути, нюхати і відчувати об'єкти віртуального світу, тобто повністю занурюється в інший світ. Повноцінна VR-система занурення складається з таких компонентів: 
полісенсорні апаратні засоби, що забезпечують доступ користувача до віртуального середовища (шоломи з дисплеями, сенсорні рукавички, сенсорне взуття, сенсорні комбінезони, запахові маски, системи відстежування руху користувача та ін.); VR-симулятор, що містить ядро програмного й апаратного забезпечення, яке подає сенсорну інформацію на датчики; засоби створення ефекту, який управляє (важелі й педалі з відповідною протидією, мікрофон для вербальної і екстралінгвістичної фрорми реакції та ін.); різноманітні прикладні програми, що описують динаміку, структуру й закони взаємодії у конкретному віртуальному світі; геометрія, що є описом фрізичних властивостей об'єктів віртуального світу; а також платформа, яка забезпечує динамічний зворотний зв'язок.

Як було зазначено, пристрої, що забезпечують доступ користувача до віртуального середовища (шоломи, костюми, взуття тощо), забезпечені системами відстежування рухів (трекінговими системами, від англ. track - стежити, відстежувати). Трекінговий пристрій, що відстежує рухи очного яблука, вбудований у шолом, забезпечує зміну зображення навіть у тому разі, коли користувач ледь поведе очима. Відстежування руху пальців у рукавичках здійснює система еластичних світлопроводів і кілька десятків датчиків. $€$ також технологія з механічними датчиками, але вона складна і недосконала. Розроблені й рукавички, які не лише фріксують й інтерпретують дані з руки, а й впливають на неї - це пристрої зі зворотною тактильною дією. Англійці винайшли рукавички, основа яких - система кульок із компресором, здатним нагрівати повітря. 3 їх допомогою можна не лише відчути фактуру віртуальних об'єктів, а і їх температуру. VR-костюми теж забезпечені трекінговими системами з численними датчиками й магнітними сенсорами, які відстежують рухи усіх частин тіла. Але датчики на костюмі діють лише в магнітному полі, тому для функціонування такого костюма необхідно постійно знаходитися на спеціальній платформі.

\section{- Висновки}

Отже, у доповненій реальності віртуальні об'єкти проєктуються на реальне оточення. Змішана, або гібридна реальність об'єднує обидві реальності: доповнену та віртуальну. Віртуальна ж реальність створює свій світ, куди може зануритися людина, не взаємодіючи із зовнішнім, тоді як доповнена додає віртуальні елементи до світу реального. Отож, VR взаємодіє лише з користувачами, a AR - з усім зовнішнім світом. Наявна в науці різноплановість точок зору вчених і практиків на питання типології віртуальної реальності пояснюється неправомірним ототожненням технологій віртуальної реальності кінця 1990-х рр. і сучасних розробок у цій ссрері; відсутністю чітких критеріїв типології і відповідних методологічних підходів, що ускладнює процес класифікації видів віртуальної реальності; швидкими темпами розвитку VR-технологій, що провокує істотне відставання теорії від практики. Тим часом сфера досліджень віртуальної реальності продовжує невпинно розширюватися, триває інтеграція VR з різними сфрерами людського життя. VR- і AR-технології набувають популярності у культурних, освітніх, ігрових, бізнес-середовищах тощо. Можливо, вже незабаром віртуальна реальність стане невід'ємною частиною нашого життя і подарує людству безліч нових можливостей. 
Порушена проблематика лише починає вивчатися в українській культурології, що спонукає до глибшого проникнення у сутність процесів, що відбуваються в культурі під впливом новітніх інформаційно-комунікаційних розробок, а відтак, з'ясування можливостей застосування останніх при реалізації численних культурницьких проєктів, вироблення механізмів і методик їх використання закладами культури тощо.

\section{- Список використаних джерел}

Бауман, 3. (2008). Текучая современность (С. А. Комаров, пер. \& Ю. В. Асочаков, ред.). Питер.

Воройский, Ф.С.(2003). Информатика. Новый систематизированный толковый словарь (3-е изд.). ФИЗМАТЛИТ.

Гидденс, Э. (2005). Устроение общества. Очерк теории структурации (2-е изд.; И. Тюрина, пер.). Академический проект.

Дацюк, С. (б.г.). Виртуальная реальность. Взято 14 апреля, 2021 из http://www.uis.kiev. ua/ _xyz//vr_enc.html.

Журба, М. А. (2014). Віртуальна реальність: різновекторні пошуки. Гілея: науковий вісник, 86, 171-175.

Засєкін, А. А. (2012). Віртуальне спілкування як чинник особистісних змін студентської молоді [Автореферат дисертації кандидата психологічних наук]. Київський університет імені Бориса Грінченка.

Кравцов, А. А. (2016). Исследование и разработка инсоормационной системы c технологией интерактивной визуализации средствами дополненной реальности [Авторефрерат диссертации кандидата технических наук]. Кубанский государственный аграрный университет, Краснодар.

Лучинкіна, А. І. (2014). Психологічні закономірності соціалізації особистості у віртуальному просторі [Автореферат дисертації доктора психологічних наук]. Інститут психології імені Г. С. Костюка, Київ.

Макеев, С. Н., \& Макеев, А. Н. (2013). Генезис понятия расширенной реальности. Учебный эксперимент в образовании, 4(68), 8-14.

Опенков, М. Ю. (2001). От Диониса до Делеза: философия виртуальности. Вестник Поморского университета. Серия: Гуманитарные и социальные науки, 1, 68-74.

Орехов, С. И. (2002). Поиск виртуальной реальности [Монография]. Омский государстенный педагогический университет.

Смерічевський, Е. Ф. (2002). Інформаційна цивілізація: проблема віртуальної реальності в суспільному розвитку [Автореферат дисертації кандидата філософфських наук]. Донецький національний університет.

Azuma, R. T. (1997). A Survey of Augmented Reality. Presence: Teleoperators and Virtual Environments, 6, 4, 355-385. http://www.cs.unc.edu/ azuma/ARpresence.pdf.

Edwin. (б.г.). Как работает дополненная реальность. Как работают вещи. Взято 14 апреля, 2021 из http://howitworks.iknowit.ru/paper1597.html.

IT-Enterprise. (б.г.). Технологии и инновации. Дополненная реальность. Взято 14 апреля, 2021 из https://www.it.ua/ru/knowledge-base/technology-innovation/dopolnennajarealnost-ar. 
Joyce, K. (2018, March 1). AR, VR, MR, RR, XR: A Glossary To The Acronyms of the Future. VRfocus. https://www.vrfocus.com/2017/05/ar-vr-mr-rr-xr-a-glossary-to-theacronyms-of-the-future/.

Krueger, M. W. (1991). Artificial Reality: Past and Future. In S. K. Helsel \& J. P. Roth (Eds.), Virtual Reality: Theory, Practice and Promise (pp. 19-26). Meckler.

Lanier, J. (2010). You Are Not a Gadget: A Manifesto. Alfred A. Knopf. https://cmapspublic3. inmc.us/rid=1MHHS4T68-C8ZML1-6DRW/YouAreNotAGadget-Jaron\%20Lanier.pdf.

Live Animations. (б.г.). Сервисы. Взято 14 апреля, 2021 из https://liveanimations.org/services/. Milgram, P., \& Kishino, F. (1994). A Taxonomy of Mixed Reality Visual Displays. IEICE Transactions on Information and Systems, E77-D, 12, 1321-1329.

Möhring, M., Lessig, C., \& Bimber, O. (2004, November 2-5). Video See-Through AR on Consumer Cell-Phones. In ISMAR'04: International Symposium on Mixed and Augmented Reality, Proceedings of the 3rd IEEE/ACM (pp. 252-253). IEEE Computer Society. https://doi.org/10.1109/ISMAR.2004.63.

\section{- References}

Azuma, R. T. (1997). A Survey of Augmented Reality. Presence: Teleoperators and Virtual Environments, 6, 4, 355-385. http://www.cs.unc.edu/ azuma/ARpresence.pdf [in English].

Bauman, Z. (2008). Tekuchaya sovremennost' [Liquid modernity] (S. A. Komarov, Trans. \& Yu. V. Asochakov, Ed.). Piter [in Russian].

Datsyuk, S. (n.d.). Virtual'naya real'nost' [A virtual reality]. Retrieved April 14, 2021 from http:// www.uis.kiev.ua/ _xyz//vr_enc.html [in Russian].

Edwin. (n.d.). Kak rabotaet dopolnennaya real'nost'. Kak rabotayut veshchi [How Augmented Reality Works. How things work]. Retrieved April 14, 2021 from http://howitworks. iknowit.ru/paper1597.html [in Russian].

Giddens, A. (2005). Ustroenie obshchestva. Ocherk teorii strukturatsii [Organization of society. Essay on the theory of structuration] ( $2^{\text {nd }}$ ed; I. Tyurina, Trans.). Akademicheskii proekt [in Russian].

IT-Enterprise. (n.d.). Tekhnologii i innovatsii. Dopolnennaya real'nost' [Technology and innovation. Augmented reality]. Retrieved April 14, 2021 from https://www.it.ua/ru/ knowledge-base/technology-innovation/dopolnennaja-realnost-ar [in Russian].

Joyce, K. (2018, March 1). AR, VR, MR, RR, XR: A Glossary To The Acronyms of the Future. VRfocus. https://www.vrfocus.com/2017/05/ar-vr-mr-rr-xr-a-glossary-to-theacronyms-of-the-future/ [in English].

Kravtsov, A. A. (2016). Issledovanie i razrabotka informatsionnoi sistemy s tekhnologiei interaktivnoi vizualizatsii sredstvami dopolnennoi real'nosti [Research and development of an information system with the technology of interactive visualization by means of augmented reality] [Abstract of PhD Dissertation]. Kuban State Agrarian University, Krasnodar [in Russian].

Krueger, M. W. (1991). Artificial Reality: Past and Future. In S. K. Helsel \& J. P. Roth (Eds.), Virtual Reality: Theory, Practice and Promise (pp. 19-26). Meckler [in English].

Lanier, J. (2010). You Are Not a Gadget: A Manifesto. Alfred A. Knopf. https://cmapspublic3. inmc.us/rid=1MHHS4T68-C8ZML1-6DRW/YouAreNotAGadget-Jaron\%20Lanier.pdf [in English]. 
Live Animations. (n.d.). Servisy [Services]. Retrieved April 14, 2021 from https://liveanimations. org/services/ [in Russian].

Luchynkina, A. I. (2014). Psykholohichni zakonomirnosti sotsializatsii osobystosti $u$ virtualnomu prostori [Psychological regularities of socialization of the person in virtual space] [Abstract of DSc Dissertation]. G.S.Kostyuk Institute of Psychology, Kyiv [in Ukrainian].

Makeev, S. N., \& Makeev, A. N. (2013). Genezis ponyatiya rasshirennoi real'nosti [Genesis of the Concept of Augmented Reality]. Uchebnyi eksperiment $v$ obrazovanii, 4(68), 8-14 [in Russian].

Milgram, P., \& Kishino, F. (1994). A Taxonomy of Mixed Reality Visual Displays. IEICE Transactions on Information and Systems, E77-D, 12, 1321-1329 [in English].

Möhring, M., Lessig, C., \& Bimber, O. (2004, November 2-5). Video See-Through AR on Consumer Cell-Phones. In ISMAR'04: International Symposium on Mixed and Augmented Reality, Proceedings of the 3rd IEEE/ACM (pp. 252-253). IEEE Computer Society. https://doi.org/10.1109/ISMAR.2004.63 [in English].

Openkov, M. Yu. (2001). Ot Dionisa do Deleza: filosofiya virtual'nosti [From Dionysus to Deleuze: Philosophy of Virtuality]. Vestnik Pomorskogo universiteta. Seriya: Gumanitarnye i sotsial'nye nauki, 1, 68-74 [in Russian].

Orekhov, S. I. (2002). Poisk virtual'noi real'nosti [Search for virtual reality] [Monograph]. Omsk State Pedagogical University [in Russian].

Smerichevskyi, E. F. (2002). Informatsiina tsyvilizatsiia: problema virtualnoi realnosti $v$ suspilnomu rozvytku [Information civilization: problem of virtual reality in the social development] [Abstract of $\mathrm{PhD}$ Dissertation]. Donetskyi natsionalnyi universytet [in Ukrainian].

Voroiskii, F. S. (2003). Informatika. Novyi sistematizirovannyi tolkovyi slovar' [Computer science. New systematized explanatory dictionary] ( $3^{\text {rd }}$ ed.). FIZMATLIT [in Russian].

Zasiekin, A. A. (2012). Virtualne spilkuvannia yak chynnyk osobystisnykh zmin studentskoi molodi [Virtual communication as a factor of personal changes of student youth] [Abstract of PhD Dissertation]. Borys Hrinchenko Kyiv University [in Ukrainian].

Zhurba, M. A. (2014). Virtualna realnist: riznovektorni poshuky [Virtual reality: multi-vector searches]. Hileya: scientific bulletin, 86, 171-175 [in Ukrainian]. 


\section{VIRTUAL, AUGMENTED AND MIXED REALITY: THE ESSENCE OF CONCEPTS AND SPECIAL FEATURES OF RELEVANT COMPUTER SYSTEMS}

\section{- Viktoriia Volynets}

- PhD in Cultural Studies, ORCID: 0000-0003-3783-508X, e-mail: vika-volynets@ukr.net, Kyiv National University of Culture and Arts, Kyiv, Ukraine

\section{- Abstract}

The purpose of the article is to reveal the essence of the concepts of "virtual reality", "augmented reality", "mixed reality", as well as to find out the typological differences of the relevant computer systems. The research methodology is based on the application of the dialectical method, which allows us to reveal the special features of virtual / augmented / mixed realities through the prism of the dialectic of interaction between technology and man. The scientific novelty of the findings is a clear distinction between the concepts of "virtual reality", "augmented reality", "mixed reality" - the key concepts of immersive information technology, the inappropriate use of which as synonyms leads to the unjustified use of special vocabulary. In addition, the article reveals the essence and main differences between computer VR-, AR-, XR-systems, which is extremely important in the framework of Ukrainian cultural studies, a science that is now actively involved in the study of unprecedented social changes under the influence of the latest information and communication technologies. Conclusions. The diversity of views of scientists and practitioners on the typology of virtual reality, as well as the concepts of "virtual reality", "augmented reality", "mixed reality", is explained by the inappropriate identification of virtual reality technologies of the late 1990s and modern developments in this area; the lack of clear typology criteria and appropriate methodological approaches, which complicates the process of classification of types of virtual reality; the rapid development of VR-technologies, which provokes a significant gap between theory and practice. Meanwhile, the field of virtual reality research continues to expand steadily, and the integration of VR with various spheres of human life is ongoing. VR and AR technologies are gaining popularity in cultural, educational, gaming, business environments, etc. It is possible that in the near future, virtual reality will become an integral part of our lives and give humanity many new opportunities. The issue under discussion is just beginning to be studied in Ukrainian culturology, which encourages deeper penetration into the essence of the processes occurring in culture under the influence of the latest information and communication developments, and therefore, clarification of the possibilities of using the latter in the implementation of numerous cultural projects, developing mechanisms and methods for their use by cultural institutions, etc.

Keywords: virtual reality; augmented reality; mixed reality; computer virtual reality; computer technology 


\section{ВИРТУАЛЬНАЯ, ДОПОЛНЕННАЯ И СМЕШАННАЯ РЕАЛЬНОСТЬ: СУЩНОСТЬ ПОНЯТИЙ И СПЕЦИФИКА СООТВЕТСТВУЮЩИХ КОМПЬЮТЕРНЫХ СИСТЕМ}

\section{- Волынец Виктория Алексеевна}

- Кандидат культурологии,

ORCID: 0000-0003-3783-508X, e-mail: vika-volynets@ukr.net, Киевский национальный университет культуры и искусств, Киев, Украина

\section{- Аннотация}

Цель статьи - раскрыть сущность понятий «виртуальная реальность», «дополненная реальность», «смешанная реальность»; выяснить типологические различия соответствующих компьютерных систем. Методология исследования основана на применении диалектического метода, что позволил раскрыть специфику виртуальной / дополненной / смешанной реальностей через призму диалектики взаимодействия техники ичеловека. Научная новизна заключается в разграничении понятий «виртуальная реальность», «дополненная реальность», «смешанная реальность» - ключевых категорий иммерсивных информационных технологий, неправомерность употребления которых в качестве синонимов приводит к необоснованному использованию специфической лексики. Кроме того, в статье раскрыта сущность и главные различия между компьютерными VR-, AR-, XR-системами, что является крайне важным в рамках украинской культурологии - науки, которая сейчас активно включается в исследование беспрецедентных общественных изменений под влиянием новейших информационнокоммуникационных технологий. Выводы. Имеющаяся в науке разноплановость точек зрения ученых и практиков на вопросы типологии виртуальной реальности, как и понятий «виртуальная реальность», «дополненная реальность», «смешанная реальность», объясняется неправомерным отождествлением технологий виртуальной реальности конца 1990-х гг. и современных разработок в этой сфере; отсутствием четких критериев типологии и соответствующих методологических подходов, что затрудняет процесс классифрикации видов виртуальной реальности; быстрыми темпами развития VRтехнологий, что провоцирует существенное отставание теории от практики. Между тем сфера исследований виртуальной реальности продолжает неуклонно расширяться, продолжается интеграция VR с различными сферами человеческой жизни. VR- и ARтехнологии завоевывают популярность в культурных, образовательных, игровых, бизнес-средах и т.д. Затронутая проблематика только начинает изучаться в украинской культурологии, что побуждает к более глубокому проникновению в сущность процессов, происходящих в культуре под влиянием новейших информационно-коммуникационных разработок.

Ключевые слова: виртуальная реальность; дополненная реальность; смешанная реальность; компьютерная виртуальная реальность; компьютерные технологии 